\title{
Additional Surgery for New Loco-Regional Tumor Event Unknown
}

National Cancer Institute

\section{Source}

National Cancer Institute. Additional Surgery for New Loco-Regional Tumor Event

Unknown. NCI Thesaurus. Code C160446.

It is unknown if additional surgery was performed for a new loco-regional tumor event. 